\title{
Relationship Between Eyespot Severity and Productivity of Winter Wheat in Lithuania
}

\author{
Jūratė Ramanauskienė $\dot{x}^{*}$ Irena Gaurilčikienė \\ Department of Plant Pathology and Protection, \\ Institute of Agriculture, Lithuanian Research Centre for Agriculture and Forestry, \\ Instituto al. 1, LT-58344 Akademija, Kèdainiai distr., Lithuania \\ Rūta Česnulevičienè \\ Perloja Experimental Station, Lithuanian Research Centre for Agriculture and Forestry, \\ Instituto aleja. 1, Akademija, LT-58344 Kèdainiai dist., Lithuania
}

\begin{abstract}
Cereal yield loss from eyespot directly depends on the severity of the disease. The aim of this study was to establish the relationship between eyespot damage in winter wheat and components of yield of winter wheat cultivars Ada, Mulan and Tukan in Lithuania in the 2011/2012 cropping season. Several eyespot did not decrease the grain number per ear cv. of Tukan while for cvs. Ada and Mulan the decrease was 14 and 15\%, respectively; however, the grain number per ear of moderately eyespot-affected stems of cv. Ada did not differ from that of visually healthy stems. For cv. Ada, the grain weight per ear of moderately affected stems was $5.8 \%$ less and that of severely affected stems was $12.8 \%$ less than that of healthy stems, while for cv. Mulan the decrease in grain weight per ear was 40.3 and $35.5 \%$, respectively and for cv. Tukan it was 59.0 and $63.2 \%$, respectively for moderately and severely affected stems. The decrease in thousand grain weight of moderately eyespot-affected stems of cv. Ada was less (6.5\%) compared with that of cv. Mulan (31.3\%) and cv. Tukan $(55.8 \%)$. Thousand grain weight of severely eyespot-affected stems of cvs. Ada, Mulan and Tukan was 22.2, 26.0 , and $65.0 \%$, respectively, less than that of healthy stems. Screening of healthy, moderately and severely affected plants of the winter wheat varieties Ada, Mulan and Tukan for grain number per ear, grain weight per ear and TGW revealed that these varieties differed in tolerance to eyespot.
\end{abstract}

Key words: eyespot, yield loss, severity, winter wheat.

\section{Introduction}

Eyespot is one of the soil's fungal diseases, dispersed by rain splash, that commonly affect stem base of winter type cereals in temperate regions of the world with a cool and wet climate. The disease is caused by the two related species Oculimacula yallundae (Wallwork \& Spooner) Crous \& W. Gams (anamorph Helgardia herpotrichoides (Fon) Crous \& W. Gams and O. acuformis (Boerema, R. Pieters $\&$ Hamers) Crous \& W. Gams (anamorph Helgardia acuformis (Nirenberg) Crous \& W. Gams. (Crous, Groenewald, \& Gams, 2003). Both pathogens are of broad specialization and infect winter wheat, rye, triticale, barley and many perennial grasses. $O$. yallundae is a more specialized wheat eyespot pathogen, often referred to as $\mathrm{W}$ (wheat) type, but can affect other cereal crops too, and $O$. acuformis equally affects wheat and rye, and can parasitize on other Poaceae plants, designated as R (rye) type (Nirenberg, 1981; King \& Griffin, 1985). Oculimacula spp. is a necrotrophic pathogen, causing the development of eye-shaped spots at the stem base of the plant. Both Oculimacula yallundae and $O$. acuformis formed visually similar spots (Bierman et al., 2002; Burnett \& Hughes, 2004).

Eyespot is one of the most damaging diseases of winter cereals in many temperate growth regions, including Lithuania. The initial source of eyespot infection is Oculimacula yallundae and $O$. acuformis conidia, which form on affected plant debris in cool and moist weather conditions. Moisture is necessary for pathogen sporulation because conidia form only on the waterlogged straw (Rowe \& Powelson, 1973). The conidia are rain splashed a short distance from the source of infection from October to July, but most intensively in March and April. Eyespot infection of the plant is more dependent on the number of rainy days than on the content of conidia and plant age (Hollins \& Scott, 1980; Fitt \& Bainbridge, 1983; Fitt, Goulds, $\&$ Polley, 1988). Enzymes, secreted by the fungus at the disease lesion site, disturb the circulatory system of stems; disrupt water and nutrient metabolism of the upper parts of the plant under-supplied with nutrients. This leads to premature aging, white ears, smaller,

\footnotetext{
* Corresponding Author's email: jurate.ramanauskiene@1zi.lt
} 
incompletely filled grains and lodging if rainy and windy weather conditions occur (Lucas, Dyer, \& Muray, 2000). Commercially available cultivars with acceptable agronomic performance do not have adequate resistance to fungal diseases (Liatukas, Ruzgas, Razbadauskienė, Brazauskas, \& Koppel, 2012). There are several known sources of resistance to eyespot, but only three resistance genes have been described Pch1, Pch2 and Pch3 (Wei, Muranty, \& Zhang, 2011; Kwiatek, Pankiewicz, Wisniewska, Korbas, \& Danielewicz, 2012). The resistance of the varieties selected for our study is not known. The aim of this study was to establish relationship between eyespot damage and components of yield.

\section{Materials and Methods}

The impact of eyespot severity on winter wheat productivity was investigated in the crops of cultivars Ada, Mulan and Tukan in the 2011/2012 cropping season. Marked sites (50x50) for sampling naturally eyespot affected and visually healthy stems were sited on commercially grown winter wheat fields, located in the middle zone of Lithuania (cv. Ada N-Latitude 55.231229 and E-Longitude 23.521686; cv. Mulan 55.243817 and 23.515400; cv. Tukan 55.240978 and 23.515633, respectively). All these crops were drilled on September 13, 2011 with a seed rate 450 viable seeds per square meter. In tested crops common plant protection practices were used. As protection against diseases fungicide without effect on eyespot (Ceriax in dosage 1.51 ha $^{-1}$ at $\mathrm{BBCH} 31-32$ and at $\mathrm{BBCH} 55$ ) has been used.

Plant growth stages were defined according to BBCH scale (Witzenberger, Hack, \& Boom, 1989). At milk ripe stage (BBCH 75, 0507 2012), in the crop of each variety, 50 plants exhibiting symptoms of eyespot ("white ears") were marked. At fully ripe stage (BBCH 89, 0608 2012) the marked stems were removed as well as 500-stem sheaves from the marked site of the crop. Samples of healthy stems, moderately affected stems (more than half or whole stem circumference affected) and severely affected stems (whole stem-base affected and softened) were selected from these sheaves. From earlier marked stems there were symptoms of "white ears" at milk ripe stage, and we eliminated those stems whose stem-base was affected by other stem-base rots or take-all disease. The sample was supplemented with severely affected stems selected from the sheaf. The ears of the samples of all eyespot severity groups (50 stems per group) were threshed separately with a laboratory thresher "Wintersteiger LD 180" (Austria) (08 08 2012). The threshed grains were counted by a "Condator" (Germany) seed counter and weighed; the grain number per ear was established, as well as grain weight per ear (g) and 1000 grain weight (TGW, g).

\section{Results}

Screening of healthy plants, moderately and severely affected plants of the winter wheat varieties Ada, Mulan and Tukan for grain number per ear, grain weight per ear and 1000 grain weight (TGW) revealed that the varieties differed in tolerance to eyespot. Several eyespot did not decrease the grain number per ear cv. of Tukan while for cvs. Ada and Mulan the decrease was 14 and $15 \%$, respectively; however, the grain number per ear of moderately eyespot-affected stems of cv. Ada did not differ from that of visually healthy stems (Table). The data averaged over the three varieties tested showed that the grain number per ear of moderately eyespot-affected stems declined by $6.2 \%$, while that of severely affected stems by $7.7 \%$, compared with healthy stems. The grain weight per ear of moderately and severely eyespot-affected stems reduction of these cultivars revealed major varietal differences in tolerance of eyespot severity. For cv. Ada, the grain weight per ear of moderately affected stems declined by $5.8 \%$ less and that of severely affected was $12.8 \%$ less than that of healthy stems, while for cv. Mulan the decrease in grain weight per ear reduction was 40.3 and $35.5 \%$, respectively and for cv. Tukan it was 59.0 and $63.2 \%$, respectively for moderately and severely affected stems. The data averaged over the three varieties tested indicated that the grain weight per ear of the moderately eyespotaffected stems declined by $34.4 \%$ and that of severely affected stems by $44.8 \%$, compared with healthy stems. The decrease in thousand grain weight of moderately eyespot-affected stems of cv. Ada was less $(6.5 \%)$ compared with that of cv. Mulan $(31.3 \%)$ and cv. Tukan (55.8\%). Thousand grain weight of severely eyespot-affected stems of cvs. Ada, Mulan and Tukan was 22.2, 26.0 and $65.0 \%$, respectively, less than that of healthy stems. Averaged data showed that the thousand grain weight of moderately eyespotaffected stems declined by 30.9 and that of severely affected stems by 38.1, compared with healthy stems.

\section{Discussion}

The results provided in the table indicate that a reduction in grain weight per ear and TGW of the eyespot-affected plants are major parameters of the disease damage. It was also revealed that the varieties exhibited a different level of eyespot tolerance. The difference of the varieties selected for our study is not known; however, cv. Ada was distinguished by a higher tolerance of eyespot damage than cvs. Mulan and Tukan.

Cereal yield loss from eyespot directly depends on the severity of the disease. It has been reported 
Relationship between eyespot severity and yield components of different winter wheat varieties, in Lithuania in 2011/2012

\begin{tabular}{|c|c|c|c|}
\hline \multirow[t]{2}{*}{ Variety } & \multicolumn{3}{|c|}{ Eyespot severity } \\
\hline & Healthy & Moderately affected & Severely affected ${ }^{b}$ \\
\hline \multicolumn{4}{|c|}{ Grain number per ear } \\
\hline Ada & $41.83 \pm 3.60$ & $42.13 \pm 2.80$ & $35.93 \pm 2.18$ \\
\hline Mulan & $36.25 \pm 0.84$ & $31.50 \pm 1.08$ & $30.83 \pm 0.75$ \\
\hline Tukan & $41.80 \pm 1.77$ & $38.75 \pm 3.88$ & $43.91 \pm 1.61$ \\
\hline Average & 39.96 & 37.46 & 36.89 \\
\hline \multicolumn{4}{|c|}{ Grain weight per ear, $g$} \\
\hline Ada & $1.72 \pm 0.19$ & $1.62 \pm 0.21$ & $1.15 \pm 0.09$ \\
\hline Mulan & $1.24 \pm 0.05$ & $0.74 \pm 0.043$ & $0.78 \pm 0.05$ \\
\hline Tukan & $1.66 \pm 0.16$ & $0.68 \pm 0.08$ & $0.61 \pm 0.05$ \\
\hline Average & 1.54 & 1.01 & 0.85 \\
\hline \multicolumn{4}{|c|}{1000 grain weight (TGW), g \% } \\
\hline Ada & $41.12 \pm 0.73$ & $38.45 \pm 3.09$ & $32.01 \pm 2.51$ \\
\hline Mulan & $34.21 \pm 2.36$ & $23.49 \pm 0.96$ & $25.30 \pm 1.21$ \\
\hline Tukan & $39.71 \pm 1.40$ & $17.55 \pm 3.69$ & $13.89 \pm 1.22$ \\
\hline Average & 38.35 & 26.50 & 23.73 \\
\hline
\end{tabular}

a - more than half or whole stem circumference affected;

b - whole stem-base affected and softened.

that the eyespot disease reduces yield through the direct effects of lesions on the host, secondly through indirect effects of lodging. In eyespot infection experiments with artificially created attacks, yield loss in unlodged winter wheat plots was $11-12 \%$, but in lodged plots it was $18 \%$ (Scott \& Hollins, 1974). In slightly damaged winter wheat, eyespot did not affect the yield. Moderate eyespot reduced the yield per ear by $10 \%$, the number of grains per ear by $8 \%$ and 1000 grain weight by $5 \%$, while for severely damaged plants these indicators declined by 36, 29 and 15\%, respectively (Scott \& Hollins, 1974; Clarkson, 1981). The yield parameters also depend on the species of eyespot pathogens (Ray, Crook, Jenkinson P, \& Edwards, 2006). The linear dependence between severe eyespot damage and yield loss was such that each $1 \%$ increase in the percentage of stems affected by severe eyespot was associated with a yield loss of $0.21 \%$ (Jones, 1994). Based on the results of this study, it can be maintained that under Lithuania's conditions grain yield losses to eyespot disease depend not only on the environmental factors, but also on the varietal tolerance to the pathogen.

\section{Conclusions}

1. Under Lithuania's conditions grain yield losses to eyespot disease depend not only on the environmental factors, but also on the varietal tolerance.

2. Averaged data showed that the TGW of moderately eyespot-affected stems declined by 30.9 and that of severely affected stems by 38.1 , compared with healthy stems.

3. The number of grains in moderately and severely eyespot-affected winter wheat ears declined by $6.2-7.7 \%$.

4. The grain weight per ear for moderately affected plants declined by $34.4 \%$, for severely affected plants it reduced by $44.8 \%$.

\section{References}

1. Bierman, S. M., Fitt, B. D. L., van den Bosch, F., Bateman, G. L., Jenkyn, J. F., \& Welham, S. J. (2002). Changes in populations of the eyespot fungi Tapesia yallundae and T. acuformis under different fungicide regimes in successive crops 
of winter wheat, 1984-2000. Plant Pathology, 51(2), 191-201. DOI: 10.1046/j.13653059.2002.00673.x.

2. Burnett, F., Hughes, G. (2004). The development of a risk assessment method to identify wheat crops at risk from eyespot. HGCA, Project Report No. 347.

3. Clarkson, D.S. (1981). Relationship between eyespot severity and yield loss in winter wheat. Plant Pathology, 30(3), 125-131.

4. Crous, P.W., Groenewald, J.Z., Gams W. (2003). Eyespot of cereals revisited: ITS phylogeny reveals new species relationships. European Journal of Plant Pathology, 109, 841-850.

5. Fitt, B.D.L., Bainbridge, A. (1983). Dispersal of Pseudocercosporella herpotrichoides spores from infected wheat straw. Journal of Phytopathology, 106(3), 214-225. DOI: 10.1111/j.1439-0434.1983.tb00046.x.

6. Fitt, B.D.L., Goulds, A., Polley, R.W. (1988). Eyespot (Pseudocercosporella herpotrichoides) epidemiology in relation to prediction of disease severity and yield loss in winter wheat - a review. Plant Pathology, 37(3), 311-328. DOI: 10.1111/j.1365-3059.1988.tb02081.x.

7. Hollins, T.W., Scott, P.R.(1980). Epidemiology of eyespot (Pseudocercosporella herpotrichoides) on winter wheat, with particular reference to the period of infection. Annals of Applied Biology, 95(1), 19-29.

8. Jones, D.R. (1994). Evaluation of fungicides for control of eyespot disease and yield loss nationships in winter wheat. Plant Pathology, 43(5), 831-846.

9. King, J.E., Griffin, M.J. (1985). Survey of benomyl resistance in Pseudocercosporella herpotrichoides on winter wheat and barley in England and Wales in 1983. Plant Pathology, 34(2), 272-283. DOI: 10.1111/j.13653059.1985.tb01359.x.

10. Kwiatek, M., Pankiewicz, K., Wisniewska, H., Korbas, M., Danielewicz, J. (2012).
Identification of Pch1 eyespot resistance gene in the collection of wheat lines (Triticum aestivum L.). Journal of Plant Protection Research, 52(2), 254-258. DOI: 10.2478/v10045-012-0040-5.

11. Lucas, J.A., Dyer, P.S., Muray, T.D. (2000). Pathogenicity, host-specificity, and population biology of Tapesia spp., causal agents of eyespot disease of cereals. Advances in Botanical Research, 33, 226-258.

12. Liatukas, Ž., Ruzgas, V., Razbadauskienè, K., Brazauskas, G., Koppel, (2012). Winter wheat cultivars 'Kovas DS', 'Zunda DS', 'Vikaras DS', 'Kaskada DS' for high input farming: development and characterization. ZemdirbysteAgriculture, 99 (3), 255-264.

13. Nirenberg, H.I. (1981). Differenzierung der erreger der halmbruchkrankheif I. Morphologie. Z. Pflanzenkrankh. Pfanzensh., 88(5), 241-248.

14. Ray, V., Crook, M.J., Jenkinson, P., Edwards, S. G. (2006). Effect of eyespot caused by Oculimacula yallundae and $O$. acuformis, assessed visually and by competitive PCR, on stem strength associated with lodging resistance and yield of winter wheat. Journal of Experimental Botany, 57(10), 2249-2257.

15. Rowe, R.C., Powelson, R.L. (1973). Epidemiology of Cercosporella foot rot of wheat: spore production. Phytopathology, 63, 981-988.

16. Scott, P.R., Hollins, T.W. (1974). Effect of eyespot on the yield of winter wheat. Annals of Applied Biology, 78(3), 269-279.

17. Wei, L., Muranty, H., Zhang, H. (2011). Advances and prospects in wheat eyespot research: contributions from genetics and molecular tools. Journal of phytopathology, 159, 457-470.

18. Witzenberger, Hack A.H., Van den Boom T. 1989. Erlauterungen zum BBCH-Dezimal-Code fur die Entwicklungsstadien des Getreides - mit Abbildungen. Gesunde Pflanzen, 41, 384-388.

\section{Acknowledgements}

The paper presents research findings obtained through the long-term research programme "Harmful organisms in agro and forest ecosystems" (KOMAS), implemented by the Lithuanian Research Centre for Agriculture and Forestry. 